\title{
PARAS CANTIK PEMBAWA PETAKA DALAM CERITA RAKYAT SUMATRA SELATAN: "PUTRI PINANG MASAK"
}

\section{SUFFERINGS DUE TO BEAUTIFUL FACE IN A SOUTH SUMATRA FOLKTALE: "PUTRI PINANG MASAK"}

\author{
Ery Agus Kurnianto \\ Balai Bahasa Provinsi Jawa Tengah \\ Jalan Elang Raya 1, Mangun Harjo, Tembalang \\ Semarang, Jawa Tengah \\ Pos-el: eratomainaka@gmail.com
}

*)Naskah diterima: 10 Juli 2021; direvisi: 7 September 2021; disetujui: 15 Oktober 2021

\begin{abstract}
Abstrak
Hal yang menarik minat untuk mengkaji cerita rakyat "Putri Pinang Masak" adalah terepresentasinya teks mendekonstruksi tentang wacana perempuan mengenai kecantikan yang dianggap sebagai anugerah tak ternilai dan membawa kebahagiaan bagi pemilikinya. Selain itu, sepengetahuan penulis belum ada kajian yang membahas tentang cerita rakyat tersebut yang terkait dengan masalah kecantikan. Penelitian ini adalah penelitian deskriptif. Peneliti akan mendeskripsikan bagaimana tokoh mengalami penderitaan lahir dan batin akibat kecantikan yang dimilikinya. Pendekatan yang digunakan adalah pendekatan objektif. Data primer penelitian ini adalah cerita rakyat yang berasal dari Desa Senuro, Tanjung Batu, Ogan Ilir, Sumatera Selatan. Hasil penelitian menunjukkan bahwa kecantikan yang dimiliki oleh tokoh perempuan mengakibatkan penderitaan yang luar biasa. Penderitaan tersebut disebabkan perempuan dijadikan objek dalam hal pengamatan, objek kekerasan seksual, dan objek kekuasaan serta kesewenang-wenangan.
\end{abstract}

Kata kunci: cantik, petaka, cerita rakyat

\begin{abstract}
An interesting kick off that leads the researcher to investigate the folklore "Putri Pinang Masak" is the text representation that deconstructs women's discourse on the concept of beauty, as for years a beauty is considered as an invaluable gift and it brings happiness to women. Moreover, the researcher insists that there has been no study within the area that discusses the folklore concerning with the issue of beauty. This research belongs to a descriptive research as the researcher will describe how the female character experiences physical and mental sufferings due to her beauty. An objective approach is applied in this reasearch. The primary data of this research is a folklore, Putri Pinang Masak, originates from Senuro Village, Tanjung Batu, Ogan Ilir, South Sumatra. The result of the study proves that the beauty possessed by female character resulted in tremendous sufferings. As the beautiful female character has been an object of sexual violence and abuse of power, her sufferings are due to her own beauty.
\end{abstract}

Keywords: beauty, sufferings, folklore 


\section{PENDAHULUAN}

Kecantikan adalah suatu anugerah bagi perempuan dalam menjalani kehidupan sosialnya sehingga perempuan berkeinginan untuk mendapatkan kecantikan dalam dirinya. Oleh karena itu, banyak perempuan ingin menjadi cantik dengan berbagai tolok ukur atau kriteria yang harus dimiliki. Akan tetapi, mayoritas kaum hawa tersebut tidak menyadari bahwa komunitas sosial yang memunculkan keinginan untuk menjadi cantik adalah komunitas sosial yang dikonstruksi oleh laki-laki. Suatu konstruksi sosial memberikan kekuasaan dan kebebasan kepada laki-laki untuk menentukan segala konsep sosial, termasuk konsep cantik bagi kaum perempuan (Wolf, 2004:23).

Lebih lanjut Wolf (2004:4) menyatakan bahwa sosok perempuan masuk dalam kategori cantik dan menjadi pusat perhatian laki-laki jika (1) kurus; (2) tinggi; (3) warna kulit putih; (4) berambut panjang dan hitam; (5) memiliki wajah yang mulus dan simetris; (5) memiliki hidung yang mancung; (6) berbibir tipis; (7) proporsi dada yang cenderung menonjol; (8) berpinggul padat dan berisi; dan (9) kaki yang jenjang tanpa ada sedikit pun cacat atau luka yang membekas.

Bagi perempuan yang tidak memiliki kriteria tersebut akan berusaha untuk mengubah struktur tubuhnya agar dapat masuk kedalam kategoricantik. Oleh karena itu, tempat spa, salon kecantikan, program diet, dan segala upaya untuk memutihkan kulit, meskipun membutuhkan biaya yang sangat besar, tetap akan didatangi sebagai upaya untuk mendapatkan pengakuan atau menyandang predikat cantik. Mitos tentang cantik telah membelenggu dan menjadikan perempuan sebagai liyan (bukan menjadi dirinya sendiri). Perempuan tidak pernah menjadi dirinya sendiri. Perempuan akan tampil sesuai dengan tuntutan laki-laki.
Dalam hal ini, perempuan terbelenggu oleh konstruksi budaya yang diciptakan oleh laki-laki tentang kategori cantik. Hal tersebut mengakibatkan perempuan akan tampil sesuai dengan tuntutan laki-laki agar dimasukkan ke dalam kategori cantik. Sartre (dalam Prameswari, 2019:2) menyatakan bahwa terdapat tiga modus dalam konsep diri manusia, yaitu ada-pada-dirinya, adabagi-dirinya, dan ada-untuk-orang lain. Dalam hal ini, konsep yang ketigalah yang menjadikan perempuan menjadi liyan. Laki-laki menjadi subjek, dalam hal ini adalah penilai, dan perempuan diposisikan sebagai objek, dalam hal ini dinilai oleh laki-laki. Wolf (2004:24) menyatakan bahwa mitos kecantikan yang menggunakan citra kecantikan digunakan oleh kaum laki-laki untuk menentang kemajuan yang dicapai oleh perempuan.

Mitos kecantikan yang hadir dalam konstruksi budaya patriarki menyebabkan perempuan tidak dipandang sebagai sosok pribadi. Perempuan dilihat sebagai sosok yang tunduk terhadap kodratnya sebagai sosok yang cantik yang harus dapat memenuhi tuntutan laki-laki. Tuntutan tersebut sebagai representasi keinginan laki-laki agar perempuan memiliki gaya dalam berpakaian, memperhatikan bentuk dan struktur tubuhnya (langsing), dan tuntutan laki-laki ke perempuan agar memakai make up dan perhiasan sebagai unsur penambah kecantikan (Beauvoir dalam Nasiru, 2014:26).

Konstruksi tersebut merepresentasikan bahwa laki-laki memiliki kekuasaan yang lebih dibandingkan perempuan. Laki-laki memiliki kekuasaan untuk mengatur dan perempuan berada di posisi yang diatur. Dikotomi gender yang bias gender akhirnya memunculkan suatu persoalan yang menempatkan perempuan di pihak yang inferior dan laki-laki di pihak superior. 
Mitos tentang perempuan yang dikontruksi oleh kaum patriarki menganggap perempuan lemah dan menjadi pihak yang inferior menyebabkan munculnya beberapa perilaku yang menjadikan perempuan sebagai objek. Hal ini berbeda dengan mitos tentang laki-laki. Laki-laki mendapatkan label sebagai pihak yang kuat dan superior. Laki-laki memiliki kelebihan fisik dan intelektual dibandingkan perempuan. Ranah publik dianggap cocok untuk lakilaki sedangkan ranah domestik dianggap cocok untuk perempuan. Hal tersebut disebabkan laki-laki memiliki kekuatan dua kali lipat jika dibandingkan perempuan (Sumadi, 2017:25).

Label superior dan inferiorlah yang menjadi salah satu penyebab munculnya objektifikasi terhadap perempuan. Nussbaum (1995:254) menyatakan aktivitas objektifikasi muncul tatkala perempuan dianggap dan diperlakukan sebagai sebuah objek atas suatu tindakan yang dilakukan oleh pihak lain. Manzella (dalam Kasokoy, 2016:1) menyatakan bahwa perempuan dipandang di bawah laki-laki. Karena berada di bawah laki-laki, laki-laki menganggap perempuan sebagai suatu objek yang dapat diperlakukan sesuai dengan kehendak lakilaki.

Objektifikasi perempuan ternyata tidak hanya dilakukan oleh laki-laki. Perempuan pun melakukan objektifiksi terhadap kaumnya dengan memandang perempuan lain menggunakan sudut pandang laki-laki. Misalnya untuk menentukan perempuan memiliki daya tarik dari segi seksual, perempuan lain menggunakan tolok ukur laki-laki untuk menilainya. Saguni (2016:143) menyatakan bahwa mitos kecantikan yang dimaknai secara mapan adalah perempuan yang memiliki tubuh cantik. Tubuh cantik ditandai dengan kulit putih mulus dan kencang, bentuk tubuh langsing dan lekukannya menunjukkan kemon- tokan (terutama dada dan pinggul yang sempurna), serta bibir yang sensual. Hal tersebut menjadi tolok ukur laki-laki untuk menilai sosok perempuan masuk kategori sosok yang memiliki daya tarik secara seksual. Oleh sebab itu, banyak perempuan yang mencoba memenuhi kriteria tersebut agar muncul dalam dirinya dan menilai perempuan lain berdasarkan kriteria tersebut. Secara singkat dapat dikatakan bahwa perempuan melakukan objektifikasi diri sendiri (self objectification). Hal ini terjadi ketika seorang perempuan selalu menomorsatukan penampilan agar dapat tampil secara sempurna sesuai dengan kriteria yang ditetapkan oleh laki-laki.

Fenomena sosial tersebut terjadi karena muncul suatu wacana yang disebabkan oleh ketidakadilan gender hasil konstruksi budaya patriarki. Dikotomi laki-laki dan perempuan yang terjadi di masyarakat menyebabkan munculnya suatu keyakinan dalam diri perempuan bahwa perempuan menjadi milik laki-laki. Oleh karena itu muncul seseorang yang berperan sebagai subjek, mayoritas laki-laki, dan seseorang yang berperan sebagai objek, biasanya perempuan.

Julia Kristeva (dalam Handayani, 2013:1) menyatakan bahwa terjadi pereduksian terhadap makna perempuan hanya sebagai sosok yang memiliki fungsi ibu dalam konstruksi budaya patriarki. Perempuan direduksi hanya sebatas media yang memiliki fungsi reproduksi. Kedudukan perempuan sebagai ibu tidak diangap sebagai subjek, melainkan sebagai objek. Konstruksi budaya patriarki menolak perempuan, keibuan, dan feminitas karena hal-hal tersebut telah tereduksi dalam fungsi perempuan sebagai objek laki-laki dalam kaitannya dengan urusan domestik. Hal tersebut akhirnya memunculkan wacana perempuan sebagai ratu rumah tangga. Crownfield (dalam Handayani, 2013:2) me- 
nyatakan bahwa wacana-wacana tentang perempuan secara terimplisit menjadikan perempuan sebagai the other atau liyan (tidak menjadi dirinya sendiri), yaitu bukan sebagai sosok yang memiliki esensi dan potensi. Perempuan hanyalah menjadi objek laki-laki.

Persoalan penderitaan perempuan yang disebabkan oleh objektifikasi perempuan terepresentasi dalam cerita-cerita rakyat yang berjudul "Putri Pinang Masak" yang berasal dari Desa Senuro. Cerita rakyat tersebut mengisahkan sosok perempuan yang dijadikan objek oleh laki-laki. Perempuan dengan berbagai stereotipnya tanpa daya dan tanpa perlawanan telah diobjektifikasi oleh laki-laki di berbagai sektor kehidupan. Secara singkat dapat dinyatakan bahwa tokoh perempuan yang muncul dalam cerita rakyat tersebut direpresentasikan sebagai objek yang dilihat dan dinikmati oleh lakilaki. Hal inilah yang menjadi daya tarik bagi penulis untuk menelah dan menelitinya.

Desa Senuro adalah wilayah yang terletak di Kecamatan Tanjung Batu, Kabupaten Ogan Ilir, Sumatra Selatan. Desa tersebut memiliki banyak cerita rakyat yang masih beredar dan diyakini kebenarannya oleh komunitas sosialnya. Cerita rakyat tersebut menjadi khazanah kekayaan budaya yang tidak ternilai harganya dan menjadi warisan budaya dari leluhur. Kekayaan tersebut menjadi kekayaan kolektif karena sampai sekarang tidak diketahui siapa pengarangnya dan siapa yang menuturkannya untuk pertama kali.

Cerita-cerita rakyat yang ada di daerah ini merupakan karya sastra yang berupa prosa yang usianya ratusan tahun. Akan tetapi kebenaran tentang cerita rakyat tersebut masih diyakini oleh masyarakat dan pantang untuk dilanggar. Salah satunya adalah cerita rakyat yang berjudul "Putri Pinang Masak". Dalam cerita rakyat ter- sebut terucap sumpah bahwa masyarakat Desa Senuro tidak boleh memiliki paras cantik. Hal tersebut disebabkan kecantikan akan membawa malapetaka bagi pemiliknya. Masyarakat Senuro meyakini bahwa sumpah yang diucapkan oleh Putri Pinang Masak adalah suatu kebenaran. Oleh karena itu, perempuan di wilayah tersebut tidak ada yang mau bersolek.

Cerita rakyat "Putri Pinang Masak" merepresentasikan suatu bentuk perlawanan terhadap gerakan yang menggunakan citra kecantikan perempuan. Teknik yang digunakan oleh teks adalah dengan menghadirkan penderitaan-penderitaan yang dialami oleh tokoh perempuan karena memiliki paras wajah cantiknya.

Berdasarkan pada hal tersebut, masalah yang diteliti dalam tulisan ini adalah bagaimana tokoh perempuan dalam cerita rakyat "Putri Pinang Masak" ditampilkan dan bagaimana penderitaan perempuan berparas cantik yang disebabkan oleh praktik objektifikasi laki-laki tehadap perempuan yang terdapat dalam cerita rakyat "Putri Pinang Masak"? Tujuan tulisan ini adalah membongkar cerita rakyat "Putri Pinang Masak" untuk memperlihatkan bagaimana sosok perempuan dan penderitaan perempuan berparas cantik akibat praktik objektifikasi yang dilakukan oleh laki-laki terhadap perempuan dalam cerita rakyat yang berjudul "Putri Pinang Masak".

\section{LANDASAN TEORI}

Cerita rakyat yang hadir di suatu komunitas sosial dilatarbelakangi oleh keadaan sosial dan budaya yang berbeda-beda. Hampir di setiap wilayah yang ada di Indonesia memiliki cerita rakyat yang pewarisannya dilakukan secara turun temurun melalui tuturan atau ucapan (Hidayat, 2019:446). Danandjaja (2007:3-4) mengartikan cerita rakyat sebagai sastra lisan yang muncul dan berkembang di suatu masyara- 
kat. Sastra lisan ini disebarkan secara lisan dan berkecenderungan dalam bentuk yang tetap.

Cerita rakyat memiliki fungsi dan manfaat bagi komunitas sosial pemiliknya. Menurut Amin dkk. (2013:35) cerita rakyat memiliki fungsi sebagai sarana hiburan dan media edukasi. Lebih lanjut Amin dkk. menyatakan bahwa cerita rakyat digunakan sebagai media untuk berkomunikasi dan mentransfer nilai-nilai kebaikan bagi anggota masyarakat pemiliknya. Pendapat tersebut sama dengan pendapat Teeuw (1984:303-304) tentang fungsi sastra lisan yang menyatakan bahwa sastra lisan masih digunakan sebagai sarana komunikasi secara langsung oleh komunitas sosial pemiliknya. Melalui sastra lisan, masyarakat dapat menginformasikan apa yang menjadi harapan dan keinginannya. Lebih lanjut Hasanuddin W.S. (2003:191) menyatakan bahwa cerita rakyat memiliki fungsi sosial bagi komunitas sosialnya yang meliputi (1) sebagai media untuk menumbuhkembangkan integritas masyarakat; (2) sebagai media atau alat kontrol sosial masyarakat; (3) sebagai media untuk memadukan kekuatan kebersamaan yang mewujud solidaritas sosial; (4) sebagai alat untuk identifikasi identitas sosial; dan (5) sebagai alat atau media untuk menciptakan harmonisasi komunal.

Sastra lisan, termasuk di dalamnya adalah cerita rakyat, memiliki ciri-ciri. Hutomo (1991:3-4) menyatakan bahwa terdapat delapan ciri yang dapat digunakan untuk mengidentifikasi cerita rakyat. Delapan ciri tersebut adalah (1) penyebaran sastra lisan, termasuk cerita rakyat, dilakukan dari mulut ke mulut atau disebarkan secara lisan; (2) sastra lisan biasanya lahir di suatu komunitas sosial yang mayoritas masyarakatnya belum mengenal huruf dan bercorak pedesaan; (3) mendeskripsikan ciri khas budaya suatu daerah; (4) biasanya muncul tanpa nama penciptanya atau antonim. Hal tersebut disebabkan komunitas sosial pemiliknya meyakini bahwa sastra lisan adalah milik bersama; (5) memiliki corak puitis, teratur, dan berulang-ulang; (6) fakta tidak menjadi hal yang diutamakan. Hal tersebut disebabkan sastra lisan lebih memberikan penekanan terhadap fantasi atau daya khayal masyarakat; (7) muncul dalam berbagai versi; dan (8) penyampaiannya menggunakan gaya bahasa lisan yang kental dengan dialek yang kadang-kadang tidak lengkap strukturnya.

Penderitaan tokoh perempuan yang memiliki paras cantik dalam cerita rakyat Putri Pinang Masak disebabkan oleh objektifikasi yang dilakukan laki-laki. Objektifikasi terhadap perempuan bersumber dari budaya patriarki yang membuat kekuasaan laki-laki lebih besar daripada perempuan. Syarifah (2006:153) menyatakan bahwa obyektifikasi muncul ketika laki-laki melalui sarana-sarana sosial merendahkan derajat perempuan. Perempuan dijadikan sebagai objek atau komoditas yang dapat diperjual belikan.

Nusbaum (dalam Hapsarani, 2017:126127) menyatakan bahwa ada beberapa ciri yang dapat dijadikan sebagai dasar untuk menandai terjadinya objektifikasi terhadap perempuan. Ciri-ciri tersebut sebagai berikut.

Apabila seseorang menempatkan orang lain untuk mencapai tujuan objektivasi yang dikehendakinya.

1. Jika seseorang ditempatkan pada suatu posisi atau pribadi yang tidak memiliki kebebasan diri untuk memilih sesuai dengan keinginannya.

2. Jika seseorang diperlakukan sebagai sosok atau pribadi yang tidak memiliki agensi.

3. Jika seseorang diperlakukan seperti benda yang sifatnya arbiter atau dapat ditukar dengan benda yang lainnya. 
4. Jika seseorang diposisikan sebagai objek yang dapat dilukai atau disakiti, baik secara psikis ataupun fisik.

5. Jika seseorang dianggap sebagai suatu objek yang dapat dikuasai dan dimiliki.

6. Jika seseorang menganggap perasaan orang lain bukan suatu hal yang penting.

Selanjutnya Hapsarani (2017:127) menyatakan bahwa Langton (2009) menambahkan tiga ciri yang melengkapi ciri-ciri Nusbaum. Ketiga ciri tersebut sebagai berikut.

1. Jika seseorang dinilai atau diidentifikai melalui tubuh atau bagian-bagian tubuh yang ada dalam dirinya.

2. Jika seseorang mendapatkan perlakuan dari orang lain berdasarkan pada penampilan.

3. Jika seseorang dianggap dan diperlakukan sebagai pihak yang tidak dapat menyuarakan hak dan keinginannya.

\section{METODE PENELITIAN}

Jenis penelitian ini adalah penelitian $\mathrm{ku}-$ alitatif. Sumber data tulisan ini adalah cerita rakyat dari Kabupaten Ogan Ilir, Sumatera Selatan, tepatnya dari Desa Senoro, Kecamatan Tanjung Batu, yang berjudul "Putri Pinang Masak". Teknik pengumpulan data dilakukan melalui dua acara. Pertama, peneliti melakukan studi pustaka sehingga data didapatkan dalam antologi cerita rakyat Legenda Tepian Musi Buku Jilid II yang ditulis oleh Yudhy Syarofi. Buku tersebut diterbitkan oleh Pemerintah Provinsi Sumatera Selatan, Dinas Pendidikan, Kegiatan Pengelolaan Kelestarian dan Pembinaan Nilai Budaya Sumatera Selatan pada tahun 2009. Kedua, untuk dapat mengamati dan melihat kondisi sosial dan budaya komunitas sosial pemilik cerita, peneliti datang langsung ke lapangan, dan bertemu informan untuk menggali informasi tentang cerita rakyat tersebut. Penggalian informasi terkait dengan pola, gaya, pandangan hidup, dan keadaan sosial, ekonomi, budaya, serta politik komunitas sosial pemilik cerita rakyat.

Pendekatan yang digunakan adalah pendekatan objektif. Melalui pendekatan ini akan terbongkar bagaimana tokoh perempuan ditampilkan dalam cerita rakyat tersebut. Selain itu, melalui pendekatan objektif akan teridentifikasi bagaimana tokoh perempuan diperlakukan oleh tokoh lain, terutama tokoh laki-laki. Melalui dua persoalan tersebut penulis memiliki dasar dan landasan yang kuat untuk penafsiran dan pemahaman makna terhadap penderitaan tokoh perempuan akibat perilaku objektifikasi tokoh laki-laki terhadap tokoh perempuan dalam cerita rakyat tersebut dapat dibongkar.

Terdapat beberapa tahapan untuk melakukan penelaahan terhadap cerita rakyat "Putri Pinang Masak". Tahapan atau langkah tersebut adalah (1) melakukan pemahaman terhadap cerita rakyat yang dijadikan data. Melalui pembacaan, penulis akan mendapatkan pemahaman tentang permasalahan obyektifikasi terhadap tokoh perempuan yang terdapat dalam cerita rakyat "Putri Pinang Masak"; (2) melakukan studi pendahuluan. Studi pendahuluan dilakukan dengan cara membaca literatur yang membahas persoalan objektifikasi perempuan. Literatur dapat berupa buku teks dan penelitian-penelitian terdahulu yang pernah ada; (3) melakukan identifikasi dan kalsifikasi terhadap persoalan atau permasalahan yang dibahas. Penulis akan mengidentifikasi dan mengklasifikasi tindakan-tindakan objektifikasi yang dilakukan laki-laki terhadap perempuan dalam dua cerita rakyat tersebut; dan (4) mendeskripsikan bagaimana tokoh-tokoh perempuan tersebut ditampilkan dalam cerita. Selain itu, akan dideskripsikan juga bagaimana tokoh perempuan tersebut diperlakukan oleh tokoh laki-laki yang menunjuk- 
kan bentuk atau corak tindakan-tindakan objektifikasi.

\section{HASIL DAN PEMBAHASAN}

Untuk dapat membongkar objektifikasi terhadap tokoh perempuan yang dilakukan oleh tokoh laki-laki dalam cerita rakyat "Putri Pinang Masak", pemahaman terhadap bagaimana tokoh perempuan ditampilkan dalam kedua cerita rakyat tersebut perlu diurai dalam penelitian ini. Sebelumnya akan ditampilkan sinopsis cerita rakyat tersebut.

\section{Sinopsis Cerita Rakyat "Putri Pinang Masak"}

Di Negeri Palembang hiduplah seorang bangsawan yang memiliki anak perempuan. Anak perempuan tersebut benama Napisah. Napisah memiliki paras yang sangat cantik. Berita kecantikan anak perempuan tersebut tersebar dan menjadi topik pembicaraan, baik laki-laki maupun perempuan, dan kabar tersebut sampai di telinga Sunan Palembang. Muncul hasrat sang Sunan untuk memiliki dan menjadikan Napisah selirnya meskipun dia tidak pernah bertemu secara langsung.

Sang Sunan Palembang menyampaikan hasrat ini ke orang tua Napisah. Gundah hati orang tua Napisah mengetahui hal tersebut. Untuk menolak secara langsung, orang tua Napisah tidak berani. Dipasanglah strategi untuk menolak secara halus hasrat sang Sunan. Napisah lalu mandi air rendaman jantung pisang dan beberapa buah pinang. Setelah mandi, penampilan Napisah berubah. Kulitnya menjadi hitam legam, rambutnya kusut dan gimbal, serta parasnya tidak lagi cantik.

Tibalah utusan Sunan Palembang menjemput Napisah. Mengetahui penampilan Napisah, dua utusan sunan menjadi ragu. Akan tetapi, mereka tetap menjalankan perintah Sunan untuk membawa Napisah. Setelah Sunan bertemu langsung dengan
Napisah, hasratnya seketika hilang dan mengembalikan Napisah ke orang tuanya.

Napisah dan keluarganya terhindar dari hasrat sang sunan. Akan tetapi, kekhawatiran menghinggapi keluarga ini. Jika sang Sunan mengetahui keadaan yang sebenarnya, Napisah beserta keluarganya akan mendapatkan hukuman yang sangat berat. Oleh karena itu, Napisah mengasingkan dan menyembunyikan diri di suatu tempat. Di tempat baru itu, Napisah mengubah namanya menjadi Senuro. Meskipun telah mengasingkan diri dan mengubah namanya, hidup Napisah tidak bisa tenang. Dia selalu dibayangi oleh ketakutan dan kekhawatiran akan nasib keluarganya.

Hingga pada suatu saat, Napisah jatuh sakit. Sebelum menghembuskan nafas terakhirnya, ia melontarkan sumpah bahwa rakyat dan anak cucunya tidak akan memiliki wajah cantik. Jika ada yang memiliki wajah cantik, dia akan meninggal sebelum menjelma menjadi seorang perempuan dewasa. Sumpah tersebut terlontar karena Napisah tidak ingin anak cucu rakyatnya menderita lahir dan batin akibat kecantikan yang dimilikinya. Oleh masyarakat, Napisah kemudian diberi nama Putri Pinang Masak dan wilayah tempat tinggal Napisah diberi nama Desa Senuro.

\section{Perempuan dalam Cerita Rakyat "Putri Pinang Masak"}

Sejak zaman dahulu, budaya patriarki yang ada di lingkungan sosial mengonstruksi beberapa nilai yang mengategorikan perempuan sebagai sosok yang cantik. Masyarakat memandang kecantikan adalah suatu anugerah yang diberikan kepada perempuan. Hal tersebut mengakibatkan kecantikan menjadi sesuatu yang ingin dicapai oleh perempuan dalam kehidupan sosialnya. Kecantikan menjadi kekuatan tersendiri bagi perempuan untuk menarik perhatian laki-laki. 
Hal tersebut terepresentasi dalam cerita rakyat "Putri Pinang Masak". Tokoh perempuan yang ditampilkan dalam cerita rakyat tersebut adalah perempuan yang memiliki paras cantik dan memesona. Kecantikan tokoh ini menarik perhatian setiap laki-laki. Muncul dalam keinginan laki-laki untuk memiliki tokoh perempuan tersebut. Bahkan, Sunan Palembang ingin menjadikannya selir.

Napisah adalah tokoh perempuan yang terdapat dalam cerita "Putri Pinang Masak". Tokoh perempuan tersebut dimunculkan sebagai sosok perempuan yang memiliki penampilan fisik cantik dan menjadi idaman para lelaki. Rambutnya hitam panjang mengurai, warna kulitnya kuning langsat, struktur tubuhnya langsing berisi, dan memiliki wajah yang meneduhkan hati bagi siapa yang memandangnya. Kecantikan tersebut secara eksplisit dimunculkan dalam cerita. Kecantikan Napisah terepresentasi dalam kutipan pantun berikut ini.

Buah Payo berupo-rupo (Buah paya
bermacam-macam)
Sapu tangan campak ke luluk (Sapu tangan
jatuh ke luluk)
Hendak lupo dak pacak lupo (Ingin melupa
tidak dapat lupa)
Lupo sekejap di waktu tiduk (Lupa sebentar
di waktu tidur)

Pantun tersebut merepresentasikan betapa Napisah memiliki wajah yang sangat cantik. Kecantikannya tersebut telah memikat hati para lelaki yang ada di daerahnya, bahkan di luar daerahnya. Hal tersebut merepresentasikan bahwa perempuan yang memiliki paras cantik akan selalu menarik perhatian laki-laki dan menjadikan laki-laki lupa diri. Kalimat lupo sekejap di waktu tiduk merepresentasikan bahwa kecantikan sang putri membuat laki-laki yang ingin melupakannya tidak mampu melakukannya. Wajah sang putri selalu muncul dalam setiap pandangnya. Wajahnya akan hilang dan sang putri dapat dilupakan tatkala sang pemuda tertidur. Sang putri hanya dapat dilupakan tatkala seseorang berada dalam posisi tidak sadar atau tidur.

Kecantikan sang putri sampai di telinga sang Sunan Palembang. Meskipun telah memiliki banyak selir, kecantikan Napisah membangkitkan nafsu Sunan Palembang untuk menguasai dan memilikinya. Muncul hasrat sang Sunan untuk memiliki dan menjadikan sang putri menjadi salah satu selirnya. Sunan mengutus dua orang utusannya untuk menjemput dan membawa Napisah ke istana. Namun pada saat gadis itu hadir di hadapan sunan dengan wajah yang sangat jelek, sunan menolak dan mengembalikannya ke orang tuanya. Hal tersebut merepresentasikan bahwa wajah cantik yang dimiliki oleh seorang perempuan menjadi suatu simbol tertinggi nafsu manusia, sebaliknya gadis yang tidak cantik tidak akan menimbulkan nafsu manusia untuk memilikinya. Hal tersebut terepresentasi dalam kutipan berikut ini.

\begin{abstract}
Nafisah yang selama ini menjadi buah bibir di Negeri Palembang, ternyata jauh dari apa yang digambarkan. Kulitnya hitam kusam, dan rambutnya-kendati tidak kusut masai-terlihat bergumpal di beberapa bagiannya. Mana gadis cindo yang membuat sunan sangat kuat rasa inginnya menjadikan gadis itu sebagai salah satu selirnya? Kedua utusan tersebut sama sekali tidak tahu, gadis yang mereka tuju sebelumnya telah mandi dengn air rebusan jantung pisang dan serangkai pinang.

$\ldots$

Gadis itu terlepas dari bencana kehidupan. Beberapa waktu lalu, setelah mandi air rebusan jantung pisang dan pinang, Nafisah dijemput ke istanan sunan. Tentu saja penampilannya mengecewakan pimpinan Negeri Palembang itu, sehingga dia dikembalikan kepada orang tuanya.
\end{abstract}

Selain ditampilkan sebagai sosok yang cantik, Napisah juga dimunculkan sebagai 
sosok yang memiliki berbagai keterampilan yang luar biasa. Salah satunya adalah ketrampilan menganyam bambu menjadi perabot rumah tangga. Memiliki wajah cantik sekaligus keterampilan di berbagai hal menjadikan Napisah menjadi sosok perempuan yang sangat didambakan dan dinginkan oleh laki-laki. Keterampilan tersebut terepresentasi dari kutipan berikut ini.

\begin{abstract}
Pemuda itu kemudian mengangkat bakul, memutar pelan anyaman itu hingga dapat melihat semua sisinya. Aneh, anyaman dari umbang itu tidak meneteskan kuah di dalamnya. Betapa halusnya pekerjaan Senuro. Betapa sempurnanya.

"Bujang ternyata pujaan hatiku tak hanya beluru, tetapi juga sangat sakti," kata Abdulah Hamid. Lidahnya berdecak-decak selama beberapa saat.

Dalam hatinya, Abdulah Hamid telah bertekad bulat, tak ada perempuan lain yang dapat singgah di hatinya kecuali Senuro. Dia akan membangun rumah paling baik sebagai tempat tinggal mereka.
\end{abstract}

Selain cantik, dan memiliki keterampilan, Napisah atau Senuro juga memiliki budi pekerti dan kebaikan hati yang baik. Kebaikan hatinya terepresentasi dari aktivitasnya berbagi keterampilan dengan masyarakat sekitar. Hubungan sosial yang baik dengan masyarakat sekitar membuat Senuro menjadi sosok yang disegani dan dihormati oleh masyarakat. Hal tersebut terepresentasi dalam kutipan berikut ini.

Putri pembesar Negeri Palembang ini pun semakin dicintai rakyat di daerah yang baru dibuka itu. Kehalusan budi pekerti dan kecantikan wajahnya semakin menambah besarnya kecintaan rakyat kepadanya. Para pemuda pun tidak sembarang memandangnya. Mereka lebih mencintai Senuro sebagai pemimpin daripada sosoknya sebagai seorang gadis.
Kutipan tersebut merepresentasikan bahwa berhasil menjalin hubungan sosial yang baik akan memunculkan suatu sikap yang berorientasi pada suatu pembinaan terhadap kehidupan sosial yang harmonis antara individu dengan masyarakat. Hubungan tersebut akan memunculkan kecintaan dan saling menjaga antara yang anggota masyarakat yang satu dengan anggota masyarakat yang lainnya. Udu (2010:129) menyatakan bahwa suatu interaksi sosial berawal dari interaksi antarindividu yang kemudian berlanjut dengan interaksi antara individu dengan masyarakat, dalam hal ini termasuk bagaimana seorang perempuan menanggapi lingkungan komunitas sosialnya. Hubungan harmonis antara Napisah atau Senuro dengan masyarakat terepresentasi dalam kutipan berikut ini.

Kabar mengenai kecantikan Senuro pun
menyebar ke mana-mana. Namun, orang-
orang yang mengetahuin hal itu sangat
berhati-hati saat membicarakan Senuro.
Mereka mengetahui, putri berparas sangat
elok itu adalah pelarian dari Negeri
Palembang. Apabila kabar mengenai
keberadaan putri dan pengiringnya sampai
ke telinga Sunan Palembang, balak-lah yang
bakal datang

Kutipan tersebut merepresentasikan betapa masyarakat sangat mencintai dan menjaga Putri Senuro. Meskipun mereka tahu bahwa Senuro adalah pelarian dari Negeri Palembang, mereka tidak memberikan informasi tersebut ke Sunan Palembang. Mereka lebih memilih untuk diam dan merahasiakannya. Pembicaraan tentang sang putri tidak dieksploitasi karena jika Sunan Palembang mengetahui hal tersebut, sang putri akan menerima musibah yang sangat besar dan menyengsarakan sang putri. Kecintaan terhadap putri tersebut memunculkan keinginan untuk menjaga sang putri agar tetap aman dari incaran sang Sunan Palembang. 
Senuro juga ditampilkan sebagai sosok perempuan yang sangat berbakti kepada orang tua. Sang Putri merelakan dirinya berpisah dari orang tua sebagai sebuah bukti kesetiaan terhadap baktinya kepada orang tua agar orang tuanya tidak mendapatkan masalah dengan Sunan Palembang. Dia rela mengembara dan mengasingan diri di tempat yang sangat sepi agar keselamatan orang tuanya terjaga. Hal tersebut terepresentasi dalam kutipan berikut ini.

"Cepat atau lambat, kabar mengenai
kebohongan kita akan tersebar. Sunan akan
mendengar bahwa sesungguhnya saat
itu Kau hanya berpura-pura buruk rupa.
Karenanya, putriku, pergilah menajuh dari
negeri ini. Carilah tempat yang tentram.
Buatlah kehidupan yang baru lebih aman dan
nyaman bagimu," kata sang ibu.
Dengan ujung kemben libar-nya, perempuan
itu menyusut buliran air yang mulai
menurun dari sudut matanya. Hal yang
sama terjadi pada Napisah. Berat hatinya
meninggalkan ayah bunda dan Mak Rajo
yang sangat mencintainya.

Bahkan untuk menjaga orang tuanya agar tidak mendapatkan masalah dengan Sunan Palembang, Napisah menyusun strategi untuk menolak keinginan Sunan Palembang melalui tipu muslihat. Ia rela mandi air rebusan jantung pisang dan buah pinang agar tubuh putih mulusnya berubah menjadi hitam pekat. Rambutnya yang hitam tergerai dan indah berubah menjadi rambut yang gimbal dan mengumpal. Ia rela melakukan itu semua karena keinginan Sunan Palembang tidak dapat ditolak secara langsung dan terang-terangan. Menolak keinginan Sunan Palembang secara langsung akan mendatangkan musibah dan malapetaka. Setelah mandi air rebusan jantung pisang dan beberapa buah pinang, putri Napisah menjadi buruk rupa. Kejelekan rupa Napisah terepresentasi dalam kutipan ini.

\begin{abstract}
"Tuan-tuan, inilah putri kami. Mohon perlakukan dia dengan baik," katanya.

Napisah Bersama dua gadis pengiringnya duduk dengan hati-hati di samping ibunya. Utusan sunan tampak kaget, tetapi mereka berusaha menyimpannya. Salah seorang dari mereka memiringkan kepala kea rah temannya.

"Sungguh, aku tak menyangka. Ini benarbenar indah kabar dari rupa," bisiknya.

"Betul. Tetapi, kita membawa perintah. Bagaimana pun, kita tetap harus membawanya kepada sunan," temannya balas berbisik.
\end{abstract}

Ungkapan indah kabar dari rupa merepresentasikan bahwa kabar lebih cantik dari rupa nyatanya. Apa yang diceritakan tidak sesuai dengan kenyataan setelah kedua utusan tersebut bertemu secara langsung dengan Napisah. Napisah tidak secantik seperti kabar yang tersiar. Karena mandi dengan jantung pisang yang direbus bersama-sama dengan beberapa buah pinang, wajah Napisah berubah menjadi jelek dan tidak menarik lagi. Mereka tidak mengetahuibahwaituadalah siasatNapisah untuk mengelabuhi Sunan Palembang agar tidak menghendaki dirinya lagi.

\section{Penderitaan Perempuan dalam Cerita Rakyat "Putri Pinang Masak"}

Banyak faktor yang menyebabkan munculnya penderitaan yang dialami perempuan. Salah satu penyebabnya adalah tindak kekerasan yag dilakukan oleh kaum lakilaki terhadap perempuan. Tindakan tersebut muncul dikarenakan adanya pemahaman tentang konsep yang kuat dan yang lemah, yang melindungi dan yang dilindungi sebagai akibat konstruksi budaya patriarki yang dibentuk, dibangun, dikembangkan, dan dipertahankan dalam kehidupan sosial oleh kaum laki-laki. Konstruksi tersebut menempatkan perempuan di posisi yang lemah sehingga perempuan patut untuk dilindungi dan dimiliki sehingga dengan sesuka 
hati dapat diperlakukan sesuai kehendak laki-laki. Muncul berbagai regulasi untuk merespon kondisi tersebut. Salah satunya adalah Deklarasi PBB yang ditetapkan pada tahun 1993.

Pasal 1 Deklarasi PBB 1993 menyatakan bahwa kekerasan terhadap perempuan meliputi semua tindakan kekerasan yang terjadi berdasar pada perbedaan jenis kelamin. Perbuatan yang disertai ancaman dan paksaan tersebut memiliki dampak negatif terhadap perempuan yang berupa kerugian fisik maupun psikis. Aktivitas-aktivitas yang mengakibatkan perampasan kebebasan dan dilakukan secara sewenang-wenang, baik dalam ranah domestik maupun publik masuk ke dalam kategori tindak kekerasan terhadap perempuan (Khairuddin, 2002:5). Salah satu bentuk kekerasan yang dilakukan oleh laki-laki terhadap perempuan adalah objektifikasi.

Objektifikasi yang menimpa kaum perempuan berasal dari suatu kontruksi yang dibangun dan dilanggengkan oeh kaum patriarki. Konstruksi budaya tersebut menjadi penyebab laki-laki memiliki kekuasaan yang lebih besar jika dibandingkan dengan kekuasaan yang dimiliki oleh perempuan, misalnya kekuasaan laki-laki atas tubuh dan kekuasaan seksual. Jacqueline Rose dalam Butler (1999:72) berpendapat bahwa munculnya kemungkinan seksualitas datang disebabkan oleh libido laki-laki. Secara singkat dapat dikatakan bahwa libido laki-laki merupakan manifestasi kekuasaan yang dimiliki oleh laki-laki untuk menguasai dan memiliki perempuan. Hal ini mengakibatkan perempuan menduduki posisi sebagai objek pemuas libido laki-laki. Persoalan objektifikasi yang menimpa perempuan muncul dalam cerita rakyat "Putri Pinang Masak". Objektifikasi yang muncul dalam cerita rakyat tersebut adalah sebagai berikut.

\section{a. Objektifikasi Visual}

Perempuan menjadi objek visual karena dalam diri perempuan terpancar suatu kondisi yang oleh masyarakat dinamakan kecantikan. Ketika perempuan masuk ke dunia laki-laki, tidak dapat dipungkiri bahwa dia akan menjadi objek pengamatan. Perempuan akan diamati sesuai dengan keinginan dan kehendak laki-laki hingga akhirnya muncul suatu penilaian secara fisik apakah cantik atau tidak cantik. Beauvoir (2003:236) menyatakan bahwa kondisi tersebut mengakibatkan perempuan tidak dipandang sebagai subjek, melainkan dipandang sebagai objek yang tidak berdaya karena kodratnya.

Dalam cerita rakyat "Putri Pinang Masak," Napisah menjadi objek visual lakilaki karena memang dia memilik kecantikan yang luar biasa. Kecantikan Napisah terepresentasi dari deskripsi tangan putih halus, rambut hitam Panjang yang mengurai, dan bentuk tubuh yang langsing yang menjadi pengungkit libido laki-laki. Napisah menjadi objek visual terepresentasi dalam kutipan berikut ini.

\footnotetext{
"Kabar kecantikan Senuro pun menyebar ke mana-mana."

"Sungguh aku tak menyangka. Ini benarbenar indah kabar dari rupa." Bisiknya.
}

Teks secara jelas menyebutkan bahwa kecantikan Senuro atau Napisah tersebar ke mana-mana. Hal tersebut merepresentasikan bagaimana Napisah menjadi objek visual laki-laki yang kemudian sampai pada suatu penilaian bahwa dia cantik. Dia hanya dipandang sebagai objek bukan sebagai sosok pribadi yang memiliki kelebihan lain selain kecantikannya. Ketika ia mandi air rebusan jantung pisang dan beberapa biji buah pinang, penampilannya tidak lagi menarik. Parasnya tidak lagi secantik kabar yang muncul secara masif di masyarakat. 
Subjektivitas Napisah tertutup oleh penilaian laki-laki yang menjadikannya sebagai objek visual. Ketika hasil objek visual menghasilkan suatu penilaian jelek, subjektivitas perempuan akan semakin tenggelam. Akan tetapi, ketika objektivitas visual sampai pada suatu penilaian cantik, subjektifitas perempuan memiliki kesempatan untuk muncul. Hal tersebut terepresentasi dalam kutipan berikut ini.

\section{"Bujang, ternyata pujaan hatiku itu tak hanya beluru, tetapi juga sangat sakti," kata Abdul Hamid. Lidahnya berdecak-decak selama beberapa saat.}

Kutipan tersebut merepresentasikan bahwa hal utama yang menjadi daya tarik atau daya pikat tokoh Napisah atau Senuro adalah paras yang cantik dan subjektivitasnya akan terakui setelah hasil pengamatan visualnya. Hal tersebut menggambarkan munculnya fenomena sosial yang menilai perempuan berdasarkan pada tampilan fisiknya dengan mengabaikan kecerdasan dan kepribadian. Cara pandang seperti ini menyebabkan perempuan hanya dijadikan sebagai objek semata.

Kecantikannya membawa penderitaan ketika berita tersebut sampai di telinga Sunan Palembang. Sunan ingin menjadikan Napisah sebagai selir di istana. Hal inilah yang pada akhirnya membuat Napisah dan keluarganya menyusun siasat agar dapat terlepas dari libido sang Sunan Palembang. Ia kemudian mengubah penampilan dirinya menjadi sosok perempuan yang buruk rupa dengan cara mandi rendaman jantung pisang dan beberapa buah pinang. Penderitaannya tidak berhenti sampai di situ. Napisah harus rela berpisah dengan orangorang yan disayanginya untuk menghindari kemurkaan hati sang Sunan ketika sang Sunan tahu jika ia telah dibohongi oleh Napisah dan keluarganya. Akar penderitaan yang menyambangi Napisah bukanlah berasal dari pihak luar, melainkan berasal dari dirinya sendiri. Penderitaan itu muncul karena dia memiliki paras yang cantik. Terkait dengan hal tersebut Wolf (2012:90) menyatakan bahwa ketika perempuan telah melampaui batas mitos kecantikan, perempuan tidak akan pernah menduduki posisi benar karena penampilannya. Perempuan akan menjadi pihak yang salah oleh siapa saja yang ingin menyalahkan mereka dan ingin merepresinya.

\section{b. Objek Seksualitas}

Priyatna (2006:293) menyatakan bahwa terpusatnya persoalan seksualitas dalam diri laki-laki mengakibatkan seksualitas perempuan dimaknai sebagai media untuk seksualitas laki-laki. Seksualitas perempuan tidak pernah dilihat sebagai sesuatu yang mandiri. Terkait dengan hal tersebut, Dagun (1992:87) menyatakan bahwa laki-laki memiliki kebebasan untuk melakukan aktivitas seks sesuai dengan keinginan mereka. Akan tetapi perempuan dalam melakukan aktivitas seks hanya sebatas sebagai pelayan laki-laki. Lebih lanjut Wolf (2004:60) menyatakan bahwa munculnya tubuh perempuan disesuaikan dengan konsep yang dibentuk oleh kaum laki-laki. Konstruski tersebut menyebabkan perempuan menjadi terasing secara seksual. Perempuan selamanya akan menjadi objek dan fantasi seksual laki-laki. Karena hal tersebut, perempuan dihadirkan sebagai sosok yang pasif dalam urusan seksual.

Tokoh perempuan dalam cerita rakyat "Putri Pinang Masak" menjadi objek seksualitas. Napisah yang memiliki paras cantik memunculkan hasrat Sunan Palembang untuk menjadikannya sebagai selir. Hal itu muncul dalam kutipan Sunan Palembang yang ingin menjadikannya selir. Kutipan tersebut merepresentasikan bahwa Napisah telah menjadi objek seksualitas Sunan Palembang. Karena kecantikannya yang telah 
terekspos membangkitkan hasrat seksualitas sang Sunan untuk memilikinya. Napisah dijadikan objek yang dapat dinikmati, dan dimiliki sesuai dengan keinginan Sunan Palembang.

Keinginan Sunan Palembang yang akan menjadikan Napisah sebagai selir merepresentasikan bahwa perempuan dalam cerita rakyat ini ditampilkan sebagai objek dan kehadirannya hanya sebagai pelengkap kebutuhan laki-laki. Seksualitas perempuan diposisikan hanya sebagai objek pemenuhan kenikmatan laki-laki. Sebagai manusia, Napisah memang sebagai subjek yang memiliki kesadaran. Oleh karena itu, dia berusaha untuk menghindari dan menolak keinginan Sunan Palembang. Langkah yang diambilnya adalah dengan mengubah penampilannya menjadi perempuan yang buruk rupa.

\begin{abstract}
Mana gadis cindo yang membuat sunan sangat kuat rasa inginnya menjadikan gadis itu sebagai salah satu selirnya? Kedua utusan tersebut sama sekali tidak tahu, gadis yang mereka tuju sebelumnya telah mandi dengan air rebusan jantung pisang dan serangkai pinang.
\end{abstract}

Sebagai seorang perempuan, dia adalah objek. Napisah tidak dapat menjadi dirinya sendiri. Dia tidak bebas berperilaku sesuai dengan keinginannya. Bahkan ketika dia menemukan pujaan hatinya dalam pelariannya. Konstruksi budaya patriarki masih memiliki dominan yang sangat kuat dalam menentukan nasibnya. Konstruksi budaya patriarki tidak berpihak pada dirinya. Napisah harus meninggalkan dunia sebelum keinginannya untuk membina rumah tangga dengan laki-laki pilihannya terwujud. Sebuah potret ideologi patriarki dalam membumikan konstruksinya. Kematian adalah suatu perlawanan diam untuk mencapai kebebasan yang dilakukan oleh perempuan terhadap konstruksi budaya tersebut.

\section{c. Objek Kekuasaan dan Kesewenang- Wenangan}

Dalam kehidupan sosial muncul sesuatu yang sangat dihargai dan ditakuti, yaitu kekuasaan. Munculnya kekuasaan disebabkan adanya dikotomi atau pelapisan masyarakat berdasarkan peran sosial yag dimiliki. Pitrim A. Sarokin (dalam Narwoko, 2004:152) menyatakan bahwa stratifikasi dalam kehidupan sosial masyarakat muncul karena adanya pembedaan masyarakat dalam tingkatan-tingkatan sosial yang ada, yaitu tingkat sosial tinggi dan tingkat sosial rendah. Perbedaan dua tingkatan tersebut terletak pada tanggung jawab dan kekuasaan yang dimiliki. Strata sosial tinggi akan memiliki kekuasaan dan tanggung jawab yang lebih besar jika dibandingkan dengan strata sosial rendah. Dikotomi tersebut akhirnya melahirkan konsep yang dikuasai dan yang menguasai. Penguasa akan memiliki wewenang untuk menentukan nasib pihak yang dikuasai.

Konsep kekuasaan terepresentasi dalam cerita rakyat "Putri Pinang Masak." Dalam cerita rakyat tersebut tercermin pembagian kekuasaan dan wewenang antara Sunan Palembang dan Napisah. Sunan Palembang menduduki posisi sebagai penguasa dan Napisah menduduki posisi yang dikuasai. Ketika kabar kecantikan Putri Napisah terdengar oleh Sunan Palembang, muncul hasrat dalam diri sang sunan untuk memiliki dan menguasainya dengan menjadikan selir. Tatkala hasrat tersebut disampaikan, Napisah tidak memiliki keberanian untuk menolak secara terang-terangan. Menolak keinginan penguasa akan mendatangkan malapetaka bagi mereka. Napisah menjadi objek kekuasaan dan kesewenang-wenangan Sunan Palembang. Hal tersebut terepresentasi dalam kutipan berikut ini.

\footnotetext{
"Jangan mengalangi, kami utusan Sunan," kata salah seorang tamu.

"Maafkan kami Tuan. Biar pun utusan
} 
Sunan, tetap saja adab dipelihara."

"Ah, maafkan kami. Kami bermaksud menjemput Napisah. Mana dia?"

...

Di tempat itu ayah dan bunda Napisah telah duduk. Meskipun dipaksakan, keduanya menebar senyum saat mempersilakan tamunya duduk.

Basa-basi mewarnai pertemuan itu. Tuan rumah sesungguhnya sudah sangat tahu maksud kedatangan tamunya. Namun, mereka tak ingin harga dirinya diinjak, menyerahkan putri mereka begitu saja. Setelah utusan Sunan menyampaikan maksudnya, ibunda Napisah beranjak kea rah belakang pengkeng, dan keluar Bersama tiga gadis.

Kutipan tersebut merepresentasikan bagaimana kekuasaan memiliki kekuatan yang luar biasa dalam menentukan nasib seseorang. Tidak muncul keberanian untuk menolak tamu utusan Sunan Palembang pada saat mereka mengambil Napisah. Kedua orang tua Napisah juga tidak berdaya menghadapi kekuasaan yang dimiliki oleh Sunan Palembang. Sangat jelas bahwa kekuasaan memiliki daya untuk memaksa pihak lain agar menurut pada keinginan yang memiliki kekuasaan dan berpengaruh terhadap tindakan-tindakan pihak yang dikuasai. Frasa Meskipun dipaksakan, keduanya menebar senyum merepresentasikan telah terjadi represi terhadap pihak keluarga Napisah yang dilakukan oleh Sunan Palembang. Hal tersebut mengakibatkan perilaku kamuflase yang harus dilakukan oleh keluarga Napisah. Kedua orang tua Napisah tetap berbuat baik meskipun kenyataannya mereka tidak menyukai utusan Sunan Palembang datang ke rumahnya. Kekuasaan merepresentasikan kemampuan untuk memerintah dan memaksa yang diperintah untuk patuh.

Posisi menjadi objek kekuasaan dan kesewenang-wenangan membuat Napisah mengalami penderitaan yang luar biasa beratnya. Sang Putri Pinang Masak mendapatkan per- lakuan yang semena-mena dari Sunan Palembang. Dia tidak dapat berkumpul dengan keluarganya dan menentukan jodohnya sendiri. Selamanya dia harus menyembunyikan diri dan merahasiakan identitasnya. Sunan Palembang telah melakukan tindak kekerasan terhadap Napisah karena kekuasaan yang dimilikinya.

Konstruksi budaya saat itu menyepakati secara bersama bahwa menentang keinginan sunan berarti musibah dan penderitaan akan datang. Hal tersebut merepresentasikan bahwa perempuan menjadi sebuah simbol kelas sosial yang hanya dijadikan sebagai pelengkap atau pemuas hasrat lakilaki. Perempuan tidak menduduki posisi yang penting. Perempuan menjadi pihak yang minoritas dan tidak berdaya dalam menghadapi keinginan laki-laki. Tokoh Napisah telah mengalami kekerasan jiwa yang pada akhirnya memunculkan trauma psikologis dengan mengucapkan sumpah atau kutukan sebelum dia meninggal. Kutukan tersebut yang terucap seperti dalam kutipan ini.

Di tengah ketidakpastian perasaan semua
orang di sekelilingnya, Senuro berucap,
"Takkan ada di antara rakyatku dan
keturunannya yang elok serupa aku. Apabila
kelak terlahir perempuan yang serupa aku,
maka dia akan sasar."
Setelah itu, matanya meredup. Tubuhnya
yang ringkih bertambah lunglai.

Sumpah tersebut merupakan wujud rasa sakit secara psikologis yang dirasakan oleh Napisah karena memiliki wajah cantik yang menimbulkan hasrat seksual laki-laki untuk memilikinya. Penderitaan dalam pelariannya untuk menghidari keinginan Sunan Palembang telah membawa kesengsaraan jiwa dan raga. Dia harus terpisah dari orang-orang yang ia sayangi. Ia harus melakukan kebohongan demi kebohongan dan dia tidak dapat berlaku sesuai 
dengan keinginannya sendiri. Ketakutan selalu membayang dalam dirinya. Penderitaan-penderitaan tersebut ia bawa sampai ajal menjemputnya. Oleh karena itu, ia tidak ingin rakyat dan seluruh keturunannya mengalami penderitaan yang telah menimpa dirinya. Sumpah tersebut akan menghindarkan rakyatnya dari penderitaan lahir dan batin akibat kecantikan paras yang dimilikinya.

\section{PENUTUP}

Persoalan inferior dan penderitaan perempuan muncul dalam cerita rakyat. Persoalan dan penderitaan tersebut disebabkan dominasi laki-laki atas perempuan. Perempuan tidak pernah menjadi dirinya sendiri karena ruang gerak yang diberikan ke perempuan sangat terbatas, hanya di ranah domestik. Hal tersebut terepresentasi dalam cerita rakyat yang berjudul "Putri Pinang Masak"

Penderitaan yang dialami oleh tokoh perempuan, Napisah, dalam cerita rakyat "Putri Pinang Masak" berupa objektifikasi yang dilakukan laki-laki. Objektifikasi mengakibatkan penderitaan lahir dan batin bagi perempuan. Objektifikasi yang dialami tokoh perempuan dalam cerita rakyat tersebut adalah (1) objektifikasi visual; (2) objektivikasi seksual; dan (3) objektifikasi kekuasaan dan kesewenang-wenangan. Objektifikasi-objektifikasi tersebut terjadi karena tokoh Napisah memiliki paras sangat cantik yang mampu membangkitkan hasrat atau libido kaum laki-laki.

\section{DAFTAR PUSTAKA}

Abdullah, Irwan. 2004. Pendekatan Teoritis Alternatif dalam Memahami Kekerasan Terhadap Perempuan (KTP) di Indonesia. Yogyakarta: Pusat Studi Kependuduan dan Kebijakan UGM.

Amin, Irzal dkk. 2013. "Cerita Rakyat Penamaan Desa di Kerinci: Kategori dan
Fungsi Sosial Teks". Jurnal Bahasa, Sastra, dan Pengajaran. Volume 1 Nomor 1, Februari. Halaman 31-41.

Butler, Judiht. (1999). Gender Trouble : Feminism and the Subversion of the Identity (2nd ed.). New York : Routledge.

Dagun, Save M. 1992. Maskulin dan Feminin Perbedaan Pria-Wanita dalam Fisiologi, Psikologi, Seksual, Karier dan Masa Depan. Jakarta: Rineka Cipta.

Danandjaja, James. 2007. Folklor Indonesia: Ilmu Gosip, Dongeng dan lain-lain. Jakarta: Pustaka Utama Grafiti.

Handayani, Christina Siwi dkk. 2013. “Julia Kristeva: Kembalinya Eksistensi Perempuan sebagai Subyek". Subyek yang Dikekang. Jakarta: Komunitas Salihara-Hivos.

Hapsarani, Dhita. 2017. “Objektivikasi Perempuan dalam Tiga Dongeng Klasik Indonesia dari Sanggar Tumpal: Sangkuriang, Jaka Tarub, dan Si Leungli". Paradigma Jurnal Kajian Budaya. Volume 7, Nomor 2. Halaman 124-137

Hasanuddin WS. 2003. Transformasi dan Produksi Sosial Teks Melalui Tanggapan dan Penciptaan Karya Sastra. Bandung: Dian Aksara Press.

Hidayat, Wahyu Al dkk. 2019. "Struktur dan Fungsi Cerita Rakyat Benayuk Versi Desa Sepala Dalung Kabupaten Tana Tidung: Kajian Strukturalisme Naratologi". Jurnal Ilmu Budaya. Volume 3 No. 4. Oktober. Hal. 422-452.

Hutomo, Suripan Sadi. 1991. Mutiara yang Terlupakan: Pengantar Studi Sastra Lisan. Surabaya: HISKI Jawa Timur.

Khairuddin-NM; Ramandey, Rebeka; Okoseray, Magdalena; Marsum; La Pona. 2002. Belenggu dan Kekerasan Terhadap Perempuan. Yogyakarta: Kerjasama Pusat Studi Kependudukan dan Kebijakan Universitas Gadjah Mada dengan Ford Foundation.

Kosakoy, Joane Priskila. 2016. “Represen- 
tasi Perempuan dalam Film Star Wars VII: The Force Awakens" Jurnal E-Komunikasi Vol 4. No.1 Tahun 2016 Halaman $1-12$.

Narwoko, J. Dwi dan Bagong Suyanto. 2004. Sosiologi, Teks Pengantar dan Terapan. Jakarta: Kencana.

Nussbaum, Martha C. 1995. Objectification. Philosophy and Public Affairs 24, no. 4 (Oktober). Halaman 249-291.

Prameswari, Ni Putu Laksmi Mutiara. 2019. "Feminisme Eksistensial Simone De Beauvoir: Perjuangan Perempuan di Ranah Domestik". Jurnal Ilmiah Sosiologi (Sorot). Volume 1. Nomor 2 (Agustus). Halaman 1-13.

Priyatna Prabasmoro. Aquarini. 2006. Kajian Budaya Feminis Tubuh Sastra dan Budaya Pop. Yogjakarta: Jalasutra.

Saguni, Suarni Syam dan Baharman. 2016.

“Narasi Tentang Mitos Kecantikan dan
Tubuh Perempuan dalam Sastra Indonesia Mutakhir: Studi atas Karya-Karya Cerpenis Indonesia." Jurnal Retorika, Volume 9, Nomor 2, Agustus. Halaman $142-148$.

Sumadi. 2017. "Islam dan Seksualitas: Bias Gender dalam Humor Pesantren." Jurnal el Harakah. Volume 19, Nomor 1. Halaman 21-40.

Syarifah. 2006. Kebertubuhan Perempuan dalam Pornografi. Jakarta : Kota Kita.

Synnott, Antonio. 2007. Tubuh Sosial. Jalasutra: Yogyakarta.

Teeuw, A. 1984. Sastra dan Ilmu Sastra Pengantar Teori Sastra. Jakarta: Pustaka Jaya. Udu, Sumiman. 2009. Perempuan Dalam Kabanti. Yogyakarta: Diandra.

Wolf, Naomi. (2004). Mitos Kecantikan: Kala Kecantikan Menindas Perempuan. Yogyakarta: Niagara. 